\title{
HTR2A wt Allele
}

National Cancer Institute

\section{Source}

National Cancer Institute. HTR2A wt Allele. NCI Thesaurus. Code C51467.

Human HTR2A wild-type allele is located within 13q14-q21 and is approximately $63 \mathrm{~kb}$ in length. This allele, which encodes 5-hydroxytryptamine $2 \mathrm{~A}$ receptor protein, is involved in several processes that activate a PI-calcium second messenger system via G-protein association, such as tracheal smooth muscle contraction, bronchoconstriction, and control of aldosterone production. 